\title{
Dioszegia antarctica sp. nov. and Dioszegia cryoxerica sp. nov., psychrophilic basidiomycetous yeasts from polar desert soils in Antarctica
}

\author{
Correspondence \\ Álvaro Fonseca \\ amrf@fct.unl.pt
}

\author{
Laurie B. Connell, ${ }^{1}$ Regina Redman, ${ }^{2,3}$ Russel Rodriguez, ${ }^{4,5}$ Anne Barrett, ${ }^{1}$ \\ Melissa Iszard ${ }^{1}$ and Álvaro Fonseca ${ }^{6}$ \\ ${ }^{1}$ School of Marine Sciences, University of Maine, 5735 Hitchner Hall, Orono, ME 04469, USA \\ ${ }^{2}$ College of Forest Resources, University of Washington, Seattle, WA 98195, USA \\ ${ }^{3}$ Adaptive Symbiotic Technologies, Seattle, WA 98125, USA \\ ${ }^{4}$ US Geological Survey, Western Fisheries Research Center, Seattle, WA 98115, USA \\ ${ }^{5}$ Department of Biology, University of Washington, Seattle, WA 98195, USA \\ ${ }^{6}$ Centro de Recursos Microbiológicos (CREM), Departamento de Ciências da Vida, Faculdade de \\ Ciências e Tecnologia, Universidade Nova de Lisboa, 2829-516 Caparica, Portugal
}

South Victoria Land (Antarctica) exhibits some of the most extreme conditions on Earth, with very dry and cold locations, as well as some highly saline sites, with soils characterized by low moisture and very low organic content (e.g. Connell et al., 2008). Yet a variety of fungi, including yeasts, have been cultured from (Connell et al., 2006, 2008; Vishniac, 2006a) or detected in (Fell et al., 2006) these soils. During a sampling campaign in the 20032004 austral summer (November 2003-January 2004), several strains of two putative novel species of Dioszegia

Abbreviation: ITS, internal transcribed spacer.

The GenBank/EMBL/DDBJ accession numbers for the LSU rRNA gene D1/D2 domain sequences of strains ANT-03-116 ${ }^{\top}$ and ANT-03$071^{\top}$ are respectively FJ640575 and FJ640562 and those for the ITS sequences of ANT-03-116 ${ }^{\top}$ and ANT-03-071 ${ }^{\top}$ are DQ402529 and FJ640565.

Details of sampling sites and a neighbour-joining tree based on D1/D2 sequences are available as supplementary material with the online version of this paper. (named Dioszegia sp. 1 and Dioszegia sp. 2) were isolated from soil samples in Taylor Valley (Connell et al., 2008). The two taxa had been detected previously by Connell et al. (2006) in the same region during the 2002-2003 field season. The genus Dioszegia currently includes 13 species, which give rise to conspicuously orange-coloured colonies and may or may not produce ballistoconidia (Bai et al., 2002; Inácio et al., 2005; Takashima et al., 2001; Wang et al., 2003, 2008). All members of the genus form a monophyletic group (the Dioszegia clade) in the Tremellales (Tremellomycetes, Agaricomycotina) according to phylogenetic analyses of SSU and LSU (D1/D2) rRNA gene sequences (e.g. Inácio et al., 2005; Wang et al., 2003, 2008). The majority of Dioszegia species were isolated from plant leaves (Wang et al., 2008), but some species may occur in soils and roots (Renker et al., 2004; Vishniac, 2006b) and one species, Dioszegia statzelliae, was isolated from soil in Antarctica (Inácio et al., 2005; Thomas-Hall et al., 2002). Here, we present the descriptions of two novel species of Dioszegia from Antarctic soils. 
Details on strain isolation were given by Connell et al. (2008). The origin of the strains studied is given in Table 1. Collection site data are given in Supplementary Table S1, available in IJSEM Online. Phenotypic characterization was carried out according to Yarrow (1998) and included the determination of growth in liquid YPD medium up to 3 weeks at $4,6,8.5,10,12,15,18,20,25,30$ and $37^{\circ} \mathrm{C}$. Physiological tests were incubated at $14-16{ }^{\circ} \mathrm{C}$. Production of ballistoconidia and filamentous structures were tested on cornmeal agar (CMA) and MYP (0.7\% malt extract, $0.25 \%$ soytone, $0.05 \%$ yeast extract) agar plates. Determination of siderophore production was carried out on solid agar plates based on the O-CAS assay and associated colour change as described by Pérez-Miranda et al. (2007). Isolation of genomic DNA used a MasterPure DNA extraction kit (Epicenter Inc.). An rRNA gene fragment containing the internal transcribed spacer (ITS) region, which includes the ITS1 and ITS2 spacers and the 5.8S rRNA gene, was amplified by PCR and sequenced using primers ITS5 (5'-GGAAGTAAAAGTCGTAACAAGG-3') and ITS4 (5'-TCCTCCGCTTATTGATATGC$3^{\prime}$ ) (White et al., 1990) as described previously (Connell et al., 2006). The D1/D2 domains of the LSU rRNA gene were amplified by PCR and sequenced using primers FG1 (5'-TGTTTGGGAATGCAGCTC-3') and R635 (5'-GGTCCGTGTTTCAAGACGG-3') (Fell et al., 2000). Because a few ambiguous positions were found in the ITS sequences of some strains, rRNA gene amplicons from those strains were cloned using the TOPO cloning kit (Invitrogen) as described previously (Connell et al., 2006) and a few random clones were selected for sequencing. With the sequences obtained, BLAST searches in GenBank were performed to find the closest matching sequences. Selected sequences from each region were then aligned with the CLUSTAL algorithm of MEGALIGN (DNASTAR Inc.). Phylogenetic trees were computed with PAUP version $4.0 \mathrm{~b} 8$ (Sinauer Associates) using the neighbour-joining method and Kimura's two-parameter model for calculating distances. Gaps were treated as missing data. Additional sequences were retrieved from GenBank (accession numbers are indicated on the phylogenetic trees).

Phylogenetic analysis of partial LSU rRNA gene sequences (Supplementary Fig. S1) demonstrated that the 13 Antarctic isolates formed two groups in the Dioszegia clade of the Tremellales, each containing strains with identical sequences: one group comprised isolates ANT-03$012,-013,-015,-031,-037,-100,-111,-112,-114$ and -116 (representing Dioszegia sp. 2; Connell et al., 2008) and the other contained the remaining three isolates, ANT-03-071, -096 and -101 (Dioszegia sp. 1) (Table 1). LSU rRNA gene sequences of Dioszegia sp. 2 were identical to that of the type strain of Dioszegia fristingensis (PYCC $5861^{\mathrm{T}}$ ) and had a few differences from those of other isolates ascribed to the latter species (AS 2.2519, AS 2.2631, CRUB 1150 and CRUB 1152). Dioszegia sp. 1 strains differed in LSU sequences from the type strain of Dioszegia changbaiensis (AS $2.2309^{\mathrm{T}}$ ) at four nucleotide positions (three substitutions and one insertion). To further ascertain the taxonomic status of the putative novel species of Dioszegia, the sequences of the ITS region were subjected to phylogenetic analysis (Fig. 1). The ten strains of Dioszegia sp. 2 formed a sister clade to D. fristingensis from which they differed at 16-17 nucleotide positions and thus they appear to represent a separate species. The ITS sequences of strains ANT-03-013, -037 and -100 differed from the other seven strains by two nucleotide substitutions. However, these differences may represent intraspe-

Table 1. Cultures used in this study

Isolate names correspond to the original strain names from Connell et al. (2008). Strains have been deposited in the Centraalbureau voor Schimmelcultures, Utrecht, The Netherlands (CBS), and in some cases in the Portuguese Yeast Culture Collection, Caparica, Portugal (PYCC). Data on collection sites are provided in Supplementary Table S1 and by Connell et al. $(2006,2008)$.

\begin{tabular}{|c|c|c|}
\hline Isolate & Other strain names & Origin \\
\hline \multicolumn{3}{|c|}{ Dioszegia antarctica sp. nov. } \\
\hline ANT-03-116 & CBS $10920^{\mathrm{T}}$, PYCC $5970^{\mathrm{T}}$ & Soil, Taylor Valley (03 YB3) \\
\hline ANT-03-013 & CBS 10750, PYCC 5966 & Soil, Taylor Valley (03 T30) \\
\hline ANT-03-015 & CBS 10615 & Soil, Taylor Valley (03 YB3) \\
\hline ANT-03-031 & CBS 10635 & Soil, Taylor Valley (03 YB2) \\
\hline ANT-03-100 & CBS 10624 & Soil, Taylor Valley (03 YB1) \\
\hline ANT-03-111 & CBS 10626 & Soil, Taylor Valley (03 YB3) \\
\hline ANT-03-112 & CBS 10627 & Soil, Taylor Valley (03 YB3) \\
\hline ANT-03-114 & CBS 10767 & Soil, Taylor Valley (03 YB3) \\
\hline \multicolumn{3}{|c|}{ Dioszegia cryoxerica sp. nov. } \\
\hline ANT-03-071 ${ }^{\mathrm{T}}$ & CBS $10919^{\mathrm{T}}$, PYCC $5967^{\mathrm{T}}$ & Moss, Taylor Valley (03 CW moss) \\
\hline
\end{tabular}




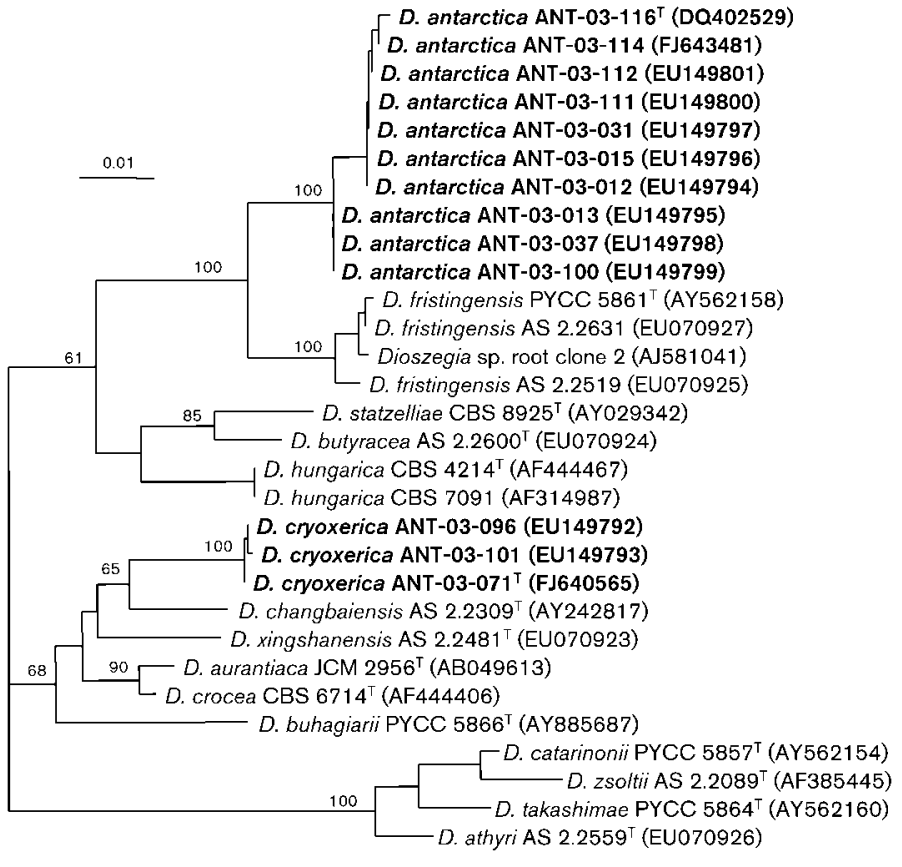

Fig. 1. Phylogenetic tree of strains of the novel species Dioszegia antarctica and Dioszegia cryoxerica and closely related species in the Dioszegia clade (Tremellales, Tremellomycetes, Agaricomycotina) obtained by neighbour-joining analysis of ITS sequences using PAUP 4.0b8. Numbers given on branches are frequencies $(>50 \%)$ with which a given branch appeared in 1000 bootstrap replications. Members of the Dioszegia catarinonii subclade were used as the outgroup. Sequences determined by the authors of the present study are in bold. Additional sequences were retrieved from GenBank. Bar, 0.01 substitutions per nucleotide position. cific variation, since no other physiological or ecological characteristics correlate with these differences. The ten strains of Dioszegia sp. 2 can be thus accommodated in a novel species, for which the name Dioszegia antarctica sp. nov. is proposed. The three strains of Dioszegia sp. 1 once again formed a sister clade to $D$. changbaiensis and, although there were a few variable sites among the former (see below), they differed from the latter species in at least 13 nucleotide positions, which confirms their separation at the species level. The three strains of Dioszegia sp. 1 can be thus accommodated in a novel species, for which the name Dioszegia cryoxerica sp. nov. is proposed.

Analysis of the ITS sequencing chromatograms of $D$. cryoxerica strains revealed up to six positions for which the corresponding nucleotide could not be attributed unambiguously because of the presence of overlapping peaks (not shown). ITS amplicons from the three D. cryoxerica strains were cloned prior to sequencing and at least six clones were selected for sequencing. The resulting chromatograms had no ambiguities, but sequences differed at the previously mentioned positions between clones from the same strain (not shown). This finding strongly suggests the existence of intrastrain ITS heterogeneity in the rRNA gene repeats. This situation is apparently uncommon among fungi, but a few examples of intrastrain ITS heterogeneity have been reported by other authors in the chytrid Pythium helicoides (Kageyama et al., 2007), the polypore genus Ganoderma (Wang \& Yao, 2005) and the basidiomycetous yeast Phaffia rhodozyma (Fell et al., 2007). The present finding appears to be restricted to $D$. cryoxerica and to the ITS region, and was not detected in $D$. antarctica.

Another unique characteristic of $D$. cryoxerica was the production of abundant true hyphae with clamp connections and haustoria by all three strains. However, no sexual structures were ever observed on the hyphae, even after prolonged incubation periods on CMA and MYP agar media at low temperature and upon transfer to water agar. Elongated conidiogenous cells that gave rise to large cylindrical conidia were frequently found, but no structures resembling basidia. The clamped mycelium arose from single cells, apparently without prior cell-cell conjugation. Mixing of the three strains in pairs yielded similar structures. The presence of haustoria suggests a possible mycoparasitic habit for this taxon. A similar situation has been reported in Cryptococcus mycelialis, another anamorphic tremellaceous yeast, which is a member of the Holtemannia clade (Golubev \& Golubev, 2003).

The two novel species share an obligately psychrophilic phenotype with $D$. statzelliae, the only other Dioszegia species isolated in Antarctica, but from a different region (Davis Base, Princess Elizabeth Land; Thomas-Hall et al., 2002). The three taxa are unable to grow at $25^{\circ} \mathrm{C}$ and optimal growth was observed between 10 and $15{ }^{\circ} \mathrm{C}$ for the two novel species (not shown) and between 15 and $18{ }^{\circ} \mathrm{C}$ for D. statzelliae (Thomas-Hall et al., 2002). Dioszegia aurantiaca and $D$. fristingensis are also unable to grow at $25{ }^{\circ} \mathrm{C}$ (e.g. Inácio et al., 2005), but they are apparently not restricted to regions with cold climates, since they were recently found in subtropical regions of China by Wang et al. (2008).

The two novel species can be distinguished phenotypically by the ability of $D$. cryoxerica to assimilate citric acid, saccharic acid and urea (Table 2). The two species also differ in siderophore production, which is strong in $D$. cryoxerica but only slightly positive in $D$. antarctica. Discrimination from other Dioszegia species is possible 
Table 2. Physiological/biochemical test responses of the newly proposed species

+, Positive; D, delayed positive; w, weak; -, negative; v, variable. Utilization of salicin and xylitol as sole carbon sources was not determined.

\begin{tabular}{|c|c|c|}
\hline Test & D. antarctica & D. cryoxerica \\
\hline \multicolumn{3}{|l|}{ Utilization of carbon sources } \\
\hline $\begin{array}{l}\text { D-Glucose, D-galactose, D-ribose, D-xylose, L-arabinose, sucrose, maltose, } \alpha, \alpha \text {-trehalose, } \\
\text { methyl } \alpha \text {-D-glucoside, cellobiose, lactose, raffinose, melezitose, inulin }\end{array}$ & + & + \\
\hline L-Sorbose, L-rhamnose & $\mathrm{V}$ & + \\
\hline D-Glucosamine & $\mathrm{V}$ & $\mathrm{V}$ \\
\hline Soluble starch & - & $\mathrm{V}$ \\
\hline Glycerol &,$+ \mathrm{D}$ & + \\
\hline Erythritol & $\mathrm{V}$ & $\mathrm{V}$ \\
\hline Ribitol, myo-inositol & $\mathrm{V}$ & + \\
\hline D-Glucitol, D-mannitol, galactitol & + & + \\
\hline Ethanol, n-hexadecane & $\mathrm{v}$ & + \\
\hline \multicolumn{3}{|l|}{ Utilization of nitrogen sources } \\
\hline Nitrate & - & - \\
\hline Nitrite & + & + \\
\hline Ethylamine & $\mathrm{V}$ & - \\
\hline L-Lysine & - & - \\
\hline Urea & - & + \\
\hline \multicolumn{3}{|l|}{ Other tests } \\
\hline Growth in vitamin-free medium & + & + \\
\hline Growth in $10 \% \mathrm{NaCl}$ plus $5 \%$ glucose & $\mathrm{V}$ & + \\
\hline Growth on $50 \%$ glucose & $\mathrm{V}$ & $\mathrm{w}$ \\
\hline
\end{tabular}

based on a combination of phenotypic characteristics, namely the ability of $D$. antarctica and D. cryoxerica to assimilate inulin and to grow without added vitamins and their inability to grow at $25{ }^{\circ} \mathrm{C}$ and to produce ballistoconidia (Table 3). D. antarctica differs from its closest relative, $D$. fristingensis, in the assimilation of inulin and in growth without added vitamins (Table 3). D. cryoxerica differs from its closest relative, D. changbaiensis, in the assimilation of inulin and inositol and growth at $25{ }^{\circ} \mathrm{C}$ (Table 3).

\section{Latin diagnosis of Dioszegia antarctica Connell, Redman, Rodriguez et Fonseca sp. nov.}

Status teleomorphosis incognitus. In medio liquido YM post 4 dies ad $14{ }^{\circ} \mathrm{C}$, cellulae ellipsoidae, 6.2-8.2 $\times 3.7-4.5 \mu \mathrm{m}$. Cultura in agaro MYP post dies 7 ad $16{ }^{\circ} \mathrm{C}$ aurantiaca, glabra, nitida, butyracea, margine integro. Ballistoconidia nullae. Mycelium et pseudomycelium non formatur. In Table
2 characteres biochemices physiologicesque declarates sunt. Characteres moleculares (culturae typi): sequentiae acidi nucleici rRNA gene 26S (D1/D2), FJ640575, et rRNA gene ITS, DQ402529, in collectione sequentiarum acidi nucleici NCBI (GenBank) depositae sunt. Typus: ANT-03-116 ${ }^{\mathrm{T}}$ isolatus ex terra, prope Taylor Valley in Antarctica, praeservatus in collectione zymotica Centraalbureau voor Schimmelcultures (CBS), Hollandia (CBS 10920 ${ }^{\mathrm{T}}$ ) et in collectione zymotica lusitanica (PYCC $5970^{\mathrm{T}}$ ).

\section{Description of Dioszegia antarctica Connell, Redman, Rodriguez et Fonseca sp. nov.}

Dioszegia antarctica (an.tarc'ti.ca. L. fem. adj. antarctica southern, referring to the south polar region, the origin of the first isolates).

Teleomorph: unknown. In YM broth, after 4 days at $14{ }^{\circ} \mathrm{C}$, cells are mainly ellipsoidal, 6.2-8.2 × 3.7-4.5 $\mu \mathrm{m}$ (Fig. 2). 
Table 3. Discriminating phenotypic characteristics of Dioszegia species

Species: 1, D. antarctica sp. nov.; 2, D. cryoxerica sp. nov.; 3, D. athyri; 4, D. aurantiaca; 5, D. buhagiarii; 6, D. butyracea; 7, D. catarinonii; 8, D. changbaiensis; 9, D. crocea; 10, D. fristingensis; 11, D. hungarica; 12, D. statzelliae; 13, D. takashimae; 14, D. xingshanensis; 15, D. zsoltii. Data were taken from Inácio et al. (2005) and Wang et al. $(2003,2008)$ or obtained in the present study for the newly proposed species; test results are scored as outlined in Table 2 .

\begin{tabular}{|c|c|c|c|c|c|c|c|c|c|c|c|c|c|c|c|}
\hline Characteristic & 1 & 2 & 3 & 4 & 5 & 6 & 7 & 8 & 9 & 10 & 11 & 12 & 13 & 14 & 15 \\
\hline \multicolumn{16}{|l|}{ Utilization of: } \\
\hline Melibiose & + & + & + & + & - & + & + & + & + & + & - & $\mathrm{w}$ & + & + & + \\
\hline Inulin & + & + & $\mathrm{W} / \mathrm{D}$ & - & - & + & - & - & - & - & - & - & - & - & - \\
\hline Ribitol & V & + & - & - & $\mathrm{D}$ & - & - & - & + & $\mathrm{D}$ & - & $\mathrm{w}$ & - & - & - \\
\hline Glucitol & + & + & $\mathrm{W} / \mathrm{D}$ & + & $\mathrm{D}$ & - & - & $\mathrm{D}$ & + & + & + & + & - & - & - \\
\hline Inositol & V & + & - & - & - & - & $-/ \mathrm{D}$ & - & - & - & $+/ \mathrm{D}$ & $\mathrm{w}$ & $-/ D$ & $\mathrm{w}$ & $-/ \mathrm{D}$ \\
\hline Erythritol & $\mathrm{V}$ & $\mathrm{V}$ & - & - & - & - & - & - & - & - & $-/ \mathrm{D}$ & - & - & - & - \\
\hline \multicolumn{16}{|l|}{ Growth in/at: } \\
\hline Vitamin-free medium & + & + & - & - & + & - & - & + & - & - & - & - & - & $\mathrm{w} / \mathrm{D}$ & - \\
\hline $25{ }^{\circ} \mathrm{C}$ & - & - & + & - & + & + & + & + & + & - & + & - & + & + & + \\
\hline \multicolumn{16}{|l|}{ Formation of: } \\
\hline Ballistoconidia & - & - & + & + & - & + & $\mathrm{v}$ & - & + & + & $\mathrm{V}$ & - & + & + & + \\
\hline Mycelium & - & + & - & - & - & - & - & - & - & - & - & - & - & - & - \\
\hline
\end{tabular}

On MYP agar, after 7 days at $16{ }^{\circ} \mathrm{C}$, colonies are dark orange, glossy, smooth and butyrous with entire margins. Ballistoconidia are not produced. Hyphae or pseudohyphae are not formed, but ramified chains of slightly elongated cells may be present. Physiological and biochemical characteristics are listed in Table 2. Nucleotide sequences of the D1/D2 domains of the LSU rRNA gene (FJ640575) and of the ITS region (DQ402529) of the type strain have been deposited in GenBank/EMBL/DDBJ.

The type strain, ANT-03-116 ${ }^{\mathrm{T}}\left(=\mathrm{CBS} 10920^{\mathrm{T}}=\right.$ PYCC $5970^{\mathrm{T}}$ ), was isolated from soil in Taylor Valley, Antarctica. Nine additional isolates from the same origin also belong to this species (Table 1).

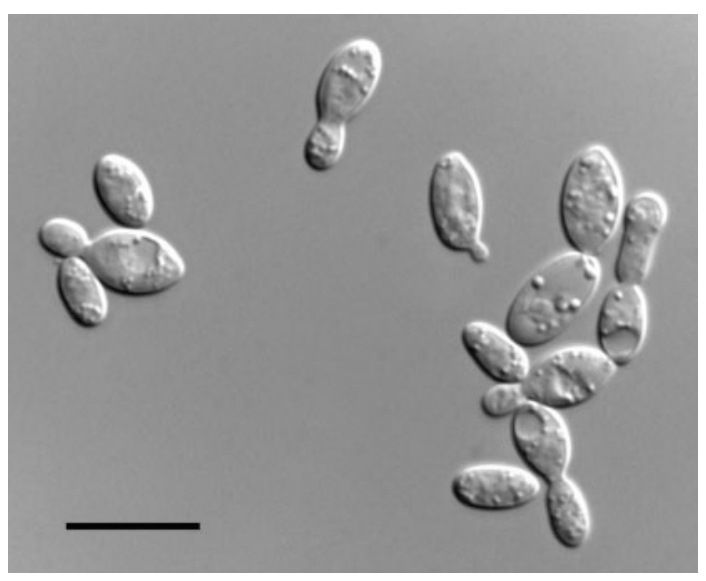

Fig. 2. Yeast cells of Dioszegia antarctica sp. nov. ANT-03-116 ${ }^{\top}$ in YM broth after 4 days at $14^{\circ} \mathrm{C}$. Bar, $10 \mu \mathrm{m}$.

\section{Latin diagnosis of Dioszegia cryoxerica Connell, Redman, Rodriguez et Fonseca sp. nov.}

Status teleomorphosis incognitus. In medio liquido YM post 4 dies ad $14{ }^{\circ} \mathrm{C}$, cellulae cylindraceae, $11.2-13.9 \times 3.3-4.2 \mu \mathrm{m}$. Cultura in agaro MYP post dies 7 ad $16{ }^{\circ} \mathrm{C}$ aurantiaca, glabra, nitida, butyracea, margine integro. Ballistoconidia nullae. Mycelium formatur, septis fibulatis. In Table 2 characteres biochemices physiologicesque declarates sunt. Characteres moleculares (culturae typi): sequentiae acidi nucleici rRNA gene 26S (D1/D2), FJ640562, et rRNA gene ITS, FJ640565, in collectione sequentiarum acidi nucleici NCBI (GenBank) depositae sunt. Typus: ANT-03-071 isolatus ex muscus, prope Taylor Valley in Antarctica, praeservatus in collectione zymotica Centraalbureau voor Schimmelcultures (CBS), Hollandia $\left(\right.$ CBS $10919^{\mathrm{T}}$ ) et in collectione zymotica lusitanica $\left(\right.$ PYCC $5967^{\mathrm{T}}$ ).

\section{Description of Dioszegia cryoxerica Connell, Redman, Rodriguez et Fonseca sp. nov.}

Dioszegia cryoxerica (cry.o.xe' ri.ca. Gr. masc. n. cryos cold; Gr. adj. xeros dry; L. fem. suff. -ica suffix used with the sense of pertaining to; N.L. fem. adj. cryoxerica cold and dry, referring to the cold and dry environment of the sampling site where the first strains were isolated).

Teleomorph: unknown. In YM broth, after 4 days at $14{ }^{\circ} \mathrm{C}$, cells are mainly cylindrical, $11.2-13.9 \times 3.3-4.2 \mu \mathrm{m}$ (Fig. 3a). On MYP agar, after 7 days at $16{ }^{\circ} \mathrm{C}$, colonies are orange, glossy, smooth and butyrous with entire margins. Ballistoconidia are not produced. Septate hyphae with clamp connections are formed from single cells (Fig. 3b). Haustoria and conidiogenous cells may develop from clamp connections (Fig. 3c, d). Physiological and biochemical characteristics are listed in Table 2. Nucleotide 

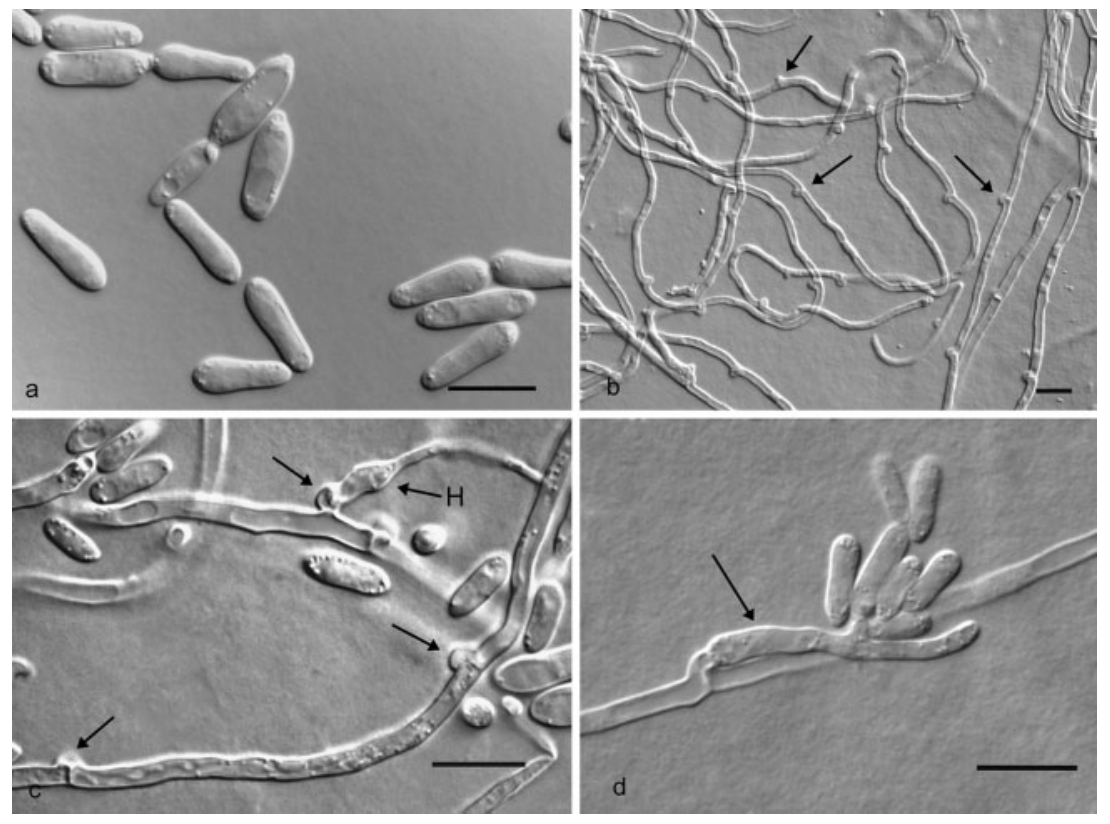

Fig. 3. Micrographs of Dioszegia cryoxerica sp. nov. ANT-03-071 ${ }^{\top}$. (a) Yeast cells in YM broth after 4 days at $14{ }^{\circ} \mathrm{C}$; (b) mycelium with clamp connections (arrows) on CMA after 1 week at $16{ }^{\circ} \mathrm{C}$; (c) mycelium with clamp connections (arrows) and an haustorium $(\mathrm{H})$ on CMA after 2 weeks at $16{ }^{\circ} \mathrm{C}$; (d) conidiogenous cell (arrow) developing from a clamp connection on CMA after 2 weeks at $16{ }^{\circ} \mathrm{C}$. Bars, $10 \mu \mathrm{m}$.

sequences of the D1/D2 domains of the LSU rRNA gene (FJ640562) and of the ITS region (FJ640565) of the type strain have been deposited in GenBank/EMBL/DDBJ.

The type strain, ANT-03-116 ${ }^{\mathrm{T}}$ (=CBS $10920^{\mathrm{T}}=$ PYCC $5967^{\mathrm{T}}$ ), was isolated from moss in Taylor Valley, Antarctica; two additional isolates from soil in the same region also belong to this species (Table 1).

\section{Acknowledgements}

We thank B. Schulz and A. Stoyles (TEA participant) for fieldwork and Raytheon Polar Support Service, UNAVCO, and PHI for logistical and laboratory support while in Antarctica. Funding was provided for this project by the NSF Office of Polar Programs to L. B. Connell and R. Rodriguez (OPP-0125611) and by the US Geological Survey (R. Rodriguez). The use of trade, firm, or corporation names in this publication is for the information and convenience of the reader. Such use does not constitute an official endorsement or approval by the US Department of Interior or the US Geological Survey of any product or service to the exclusion of others that may be suitable.

\section{References}

Bai, F. Y., Takashima, M., Jia, J. H. \& Nakase, T. (2002). Dioszegia zsoltii sp. nov., a new ballistoconidium-forming yeast species with two varieties. J Gen Appl Microbiol 48, 17-23.

Connell, L. B., Redman, R., Craig, S. D. \& Rodriguez, R. (2006). Distribution and abundance of fungi in the soils of Taylor Valley, Antarctica. Soil Biol Biochem 38, 3083-3094.

Connell, L. B., Redman, R., Craig, S. D., Scorzetti, G., Iszard, M. \& Rodriguez, R. (2008). Diversity of soil yeasts isolated from South Victoria Land, Antarctica. Microb Ecol 56, 448-459.

Fell, J. W., Boekhout, T., Fonseca, Á., Scorzetti, G. \& StatzellTallman, A. (2000). Biodiversity and systematics of basidiomycetous yeasts as determined by large subunit rDNA D1/D2 domain sequence analysis. Int J Syst Evol Microbiol 50, 1351-1371.
Fell, J. W., Scorzetti, G., Connell, L. \& Craig, S. (2006). Biodiversity of micro-eukaryotes in Antarctic Dry Valley soils with $<5 \%$ soil moisture. Soil Biol Biochem 38, 3107-3119.

Fell, J. W., Scorzetti, G., Statzell-Tallman, A. \& Boundy-Mills, K. (2007). Molecular diversity and intragenomic variability in the yeast genus Xanthophyllomyces: the origin of Phaffia rhodozyma. FEMS Yeast Res 7, 1399-1408.

Golubev, W. I. \& Golubev, N. W. (2003). A new basidiomycetous yeast species, Cryptococcus mycelialis, related to Holtermannia Saccardo et Traverso. Microbiology (English translation of Mikrobiologiia) 72, 822-827.

Inácio, J., Portugal, L., Spencer-Martins, I. \& Fonseca, Á. (2005). Phylloplane yeasts from Portugal: seven novel anamorphic species in the Tremellales lineage of the Hymenomycetes (Basidiomycota) producing orange-coloured colonies. FEMS Yeast Res 5, 1167-1183.

Kageyama, K., Senda, M., Asano, T., Suga, H. \& Ishiguro, K. (2007). Intra-isolate heterogeneity of the ITS region of rDNA in Pythium helicoides. Mycol Res 111, 416-423.

Pérez-Miranda, S., Cabirol, N., George-Téllez, R., Zamudio-Rivera, L. S. \& Fernández, F. J. (2007). O-CAS, a fast and universal method for siderophore detection. J Microbiol Methods 70, 127-131.

Renker, C., Blanke, V., Börstler, B., Heinrichs, J. \& Buscot, F. (2004). Diversity of Cryptococcus and Dioszegia yeasts (Basidiomycota) inhabiting arbuscular mycorrhizal roots or spores. FEMS Yeast Res 4, 597-603.

Takashima, M., Deak, T. \& Nakase, T. (2001). Emendation of Dioszegia with redescription of Dioszegia hungarica and two new combinations, Dioszegia aurantiaca and Dioszegia crocea. J Gen Appl Microbiol 47, 75-84.

Thomas-Hall, S., Watson, K. \& Scorzetti, G. (2002). Cryptococcus statzelliae sp. nov. and three novel strains of Cryptococcus victoriae, yeasts isolated from Antarctic soils. Int J Syst Evol Microbiol 52, 2303-2308.

Vishniac, H. S. (2006a). Yeast biodiversity in the Antarctic. In Biodiversity and Ecophysiology of Yeasts, pp. 428-440. Edited by G. Peter \& C. A. Rosa. Berlin: Springer.

Vishniac, H. S. (2006b). A multivariate analysis of soil yeasts isolated from a latitudinal gradient. Microb Ecol 52, 90-103. 
Wang, D. M. \& Yao, Y. J. (2005). Intrastrain internal transcribed spacer heterogeneity in Ganoderma species. Can J Microbiol 51, 113-121.

Wang, Q. M., Bai, F. Y., Zhao, J. H. \& Jia, J. H. (2003). Dioszegia changbaiensis sp. nov., a basidiomycetous yeast species isolated from northeast China. J Gen Appl Microbiol 49, 295-299.

Wang, Q. M., Jia, J. H. \& Bai, F. Y. (2008). Diversity of basidiomycetous phylloplane yeasts belonging to the genus Dioszegia (Tremellales) and description of Dioszegia athyri sp. nov., Dioszegia butyracea sp. nov. and Dioszegia xingshanensis sp. nov. Antonie van Leeuwenhoek 93, 391-399.
White, T. J., Bruns, T., Lee, S. \& Taylor, J. W. (1990). Amplification and direct sequencing of fungal ribosomal RNA genes for phylogenetics. In PCR Protocols: a Guide to Methods and Applications, pp. 315-322. Edited by M. A. Innis, D. H. Gelfand, J. J. Sninsky \& T. J. White. Orlando: Academic Press.

Yarrow, D. (1998). Methods for the isolation, maintenance and identification of yeasts. In The Yeasts: a Taxonomic Study, 4th edn, pp. 77-100. Edited by C. P. Kurtzman \& J. W. Fell. Amsterdam: Elsevier. 